\title{
POLE wt Allele
}

National Cancer Institute

\section{Source}

National Cancer Institute. POLE wt Allele. NCI Thesaurus. Code C106233.

Human POLE wild-type allele is located in the vicinity of 12 q24.3 and is approximately 213 $\mathrm{kb}$ in length. This allele, which encodes DNA polymerase epsilon catalytic subunit A protein, plays a role in both DNA base-excision repair and DNA replication. Mutation of the gene may be associated with both increased susceptibility to colorectal malignancies and facial dysmorphism, immunodeficiency, livedo, and short stature (FILS) syndrome. 